\section{Spectrophotometry of the Platinum Metals in the Ultraviolet Region}

\section{Determination of Platinum(IV) *}

Spektrophotometrie der Platinmetalle im UV-Bereich. III. Bestimmung von Platin(IV)

Best. von Platin(IV); SpektraIphotometrie; UV-Bereich

Jan Vorlíčk and Jan Doležal

Ore Research Institute and Department

of Analytical Chemistry, Charles University, Prague, CSSR

Received February 26, 1973; revised May 23, 1973

The present paper, which is part of a systematic study of the use of ultraviolet spectra in the analysis of the noble metals, describes the possibilities of the spectrophotometric determination of platinum(IV) as chlorocomplex within the region $200-350 \mathrm{~nm}$. An investigation of the effect of $\mathrm{pH}$ on the absorption curve revealed that in unbuffered $\mathrm{HCl}$ media $\mathrm{pH} 1-4$ the height of the absorption maximum at $262 \mathrm{~nm}$ is not affected, whereas in buffered media $\mathrm{pH} 1-9$ this height decreases up to $\mathrm{pH} 6.5$ with a slight increase after that. Determinations of $1-15 \mathrm{mg}$ of platinum showed a relative error of about $0.9 \%$. Beer's law is obeyed. $\mathrm{CrO}_{4}{ }^{-}$interferes, $\mathrm{Fe}(\mathrm{III})$ and $\mathrm{Pd}(\mathrm{II})$ interfere when present in amounts higher than $0.1 \mathrm{~g}$. According to our recent experiments, it is possible to separating platinum by extraction with, e.g., 2-methylisobutylketone. On the other hand, $35 \mathrm{~g}$ of $\mathrm{Na}_{2} \mathrm{SO}_{4}$, $20 \mathrm{~g}$ of $\mathrm{NaNO}_{3}, 60 \mathrm{~g}$ of $\mathrm{KBr}, 60 \mathrm{~g}$ of $\mathrm{KCl}, 30 \mathrm{~g}$ of $\mathrm{NaCl}, 60 \mathrm{~g}$ of $\mathrm{NaClO}_{4}, 30 \mathrm{~g}$ of $\mathrm{H}_{3} \mathrm{PO}_{4}, 50 \mathrm{~g}$ of $\mathrm{H}_{3} \mathrm{BO}_{3}$, and compounds of $\mathrm{Mn}, \mathrm{Cu}, \mathrm{Ti}, \mathrm{Zn}, \mathrm{Ca}, \mathrm{Ni}, \mathrm{Al}, \mathrm{Mg}$, $\mathrm{Rh}, \mathrm{Ir}$ and $\mathrm{Cr}$ (III) do not interfere.

* Part II: Z. Anal. Chem. 262, 365 (1972).

\section{Detection of Platinum(IV) with Largactil (Chlorpromazine Hydrochloride)}

Nachweis von Platin(IV) mit Largactil (Chlorpromazinhydrochlorid)

Nachw. von Platin(IV) mit Largactil, Chlorpromazinhydrochlorid

\section{G. S. Johar}

Dept. of Chemistry, Vikramajit Singh Sanatan Dharma College, Kanpur 208002, India

Received March 31, 1973; revised May 26, 1973

The common tranquilizer and adrenolytic drug largactil (thorazine) has been used for the microgramlevel detection of platinum(IV). Its solution in dil. hydrochloric acid gives a bluish colouration or
Table 1

\begin{tabular}{llll}
\hline Sample type & \multicolumn{3}{l}{ The Pt content } \\
\cline { 2 - 4 } & $\begin{array}{l}\text { Laboratory } \\
\text { I }\end{array}$ & $\begin{array}{l}\text { Laboratory } \\
\text { II }\end{array}$ & $\begin{array}{l}\text { Laboratory } \\
\text { III }\end{array}$ \\
\hline Solution 1 & - & $0.0050 \mathrm{~g} / 1$ & $0.0055 \mathrm{~g} / 1$ \\
Solution 2 & - & $0.0350 \mathrm{~g} / 1$ & $0.0378 \mathrm{~g} / 1$ \\
Solution 3 & - & $0.0860 \mathrm{~g} / 1$ & $0.0888 \mathrm{~g} / 1$ \\
Solution 4 & - & $0.0130 \mathrm{~g} / 1$ & $0.0135 \mathrm{~g} / 1$ \\
Catalyst & & & \\
$\quad$ solid I & $0.512 \%$ & $0.524 \%$ & $0.518 \%$ \\
$\quad$ solid II & $0.471 \%$ & $0.462 \%$ & $0.467 \%$ \\
\hline
\end{tabular}

Laboratory I: the method is not specified.

Laboratory II: spectrophotometry with $\mathrm{SnCl}_{2}(403 \mathrm{~nm})$.

Laboratory III: UV-spectrophotometry (262 nm).

The described procedure was applied with satisfactory results to the analysis of platinum solutions and reforming catalysts (see Table 1 ).

\section{Procedure}

A. Solutions containing nitric or hydrochloric acid are evaporated to dryness and the evaporation is repeated after addition of hydrochloric acid. The residue is taken up with hot $0.1 \mathrm{M} \mathrm{HCl}$ and is transferred into a volumetric flask. The absorbance is measured at $262 \mathrm{~nm}$ and the content of platinum(IV) is calculated using a calibration curve.

B. Solid Samples. The weighed sample is decomposed by a mixture of $\mathrm{HNO}_{3}$ and $\mathrm{HCl}(1: 2)$, the nitrogen oxides are removed by evaporating with hydrochloric acid to dryness, the residue is taken up with hot $0.1 \mathrm{M} \mathrm{HCl}$, and is transferred into a volumetric flask. The measurement and evaluation are performed in the same manner as above.

Dr. J. Vorlíěek CSc

Ore Research Institute

Modřanská 23

14713 Praha-4, ČSSR

greenish precipitate with a warm solution of $\mathrm{Pt}(\mathrm{IV})$. The intensity and quality of the coloured product is enhanced on adding dil. ammonia solution. Limit of detection is $40 \mu \mathrm{g} \mathrm{Pt}(\mathrm{IV})$; limit of dilution is $1: 12500$. Most cations and anions do not interfere. $\mathrm{I}^{-}, \mathrm{SCN}^{-}$, $\mathrm{VO}_{3}^{-}, \mathrm{S}_{2} \mathrm{O}_{3}{ }^{2-},\left[\mathrm{Fe}(\mathrm{CN})_{6}\right]^{4-}, \quad\left[\mathrm{Fe}(\mathrm{CN})_{5} \mathrm{NO}\right]^{2-}$, large quantities of $\mathrm{Fe}$ (III), and oxidizing ions, such as $\mathrm{IO}_{3}{ }^{-}, \mathrm{IO}_{4}^{-}, \mathrm{NO}_{2}{ }^{-}, \mathrm{CrO}_{4}{ }^{2-}, \mathrm{Cr}_{2} \mathrm{O}_{7}{ }^{2-}$, and $\left[\mathrm{Fe}(\mathrm{CN})_{6}\right]^{3-}$ interfere. In the presence of $\mathrm{Cu}(\mathrm{II}), \mathrm{Fe}(\mathrm{II}), \mathrm{Fe}(\mathrm{III})$, $\mathrm{Cr}(\mathrm{III})$, and $\mathrm{Hg}(\mathrm{I})$, the ammonia treatment step in the test must be avoided.

Dr. G. S. Johar

Dept. of Chemistry

Sanatan Dharma College

Kikramajit Singh

Vanpur 208002, India 